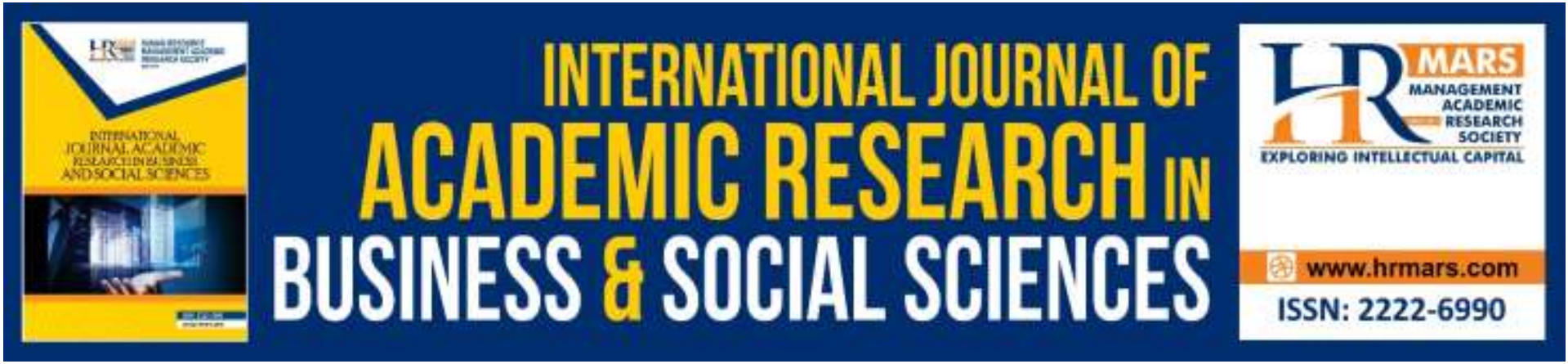

\title{
Airbnb Physical Environment Attributes and Customer Behavioral Intention: A Proposed Study
}

Normaizana Mat Nawi, Nik Alif Amri Nik Hashim, Zurena@Rena Shahril, Rasidah Hamid

To Link this Article: http://dx.doi.org/10.6007/IJARBSS/v9-i8/6230

DOI: $10.6007 /$ IJARBSS/v9-i8/6230

Received: 22 May 2019, Revised: 18 June 2019, Accepted: 30 July 2019

Published Online: 13 August 2019

In-Text Citation: (Nawi, Hashim, Shahril, \& Hamid, 209AD)

To Cite this Article: Nawi, N. M., Hashim, N. A. A. N., Shahril, Z., \& Hamid, R. (209AD). Airbnb Physical Environment Attributes and Customer Behavioral Intention: A Proposed Study. International Journal of Academic Research in Business and Social Sciences, 9(8), 144-151.

Copyright: @ 2019 The Author(s)

Published by Human Resource Management Academic Research Society (www.hrmars.com)

This article is published under the Creative Commons Attribution (CC BY 4.0) license. Anyone may reproduce, distribute, translate and create derivative works of this article (for both commercial and non-commercial purposes), subject to full attribution to the original publication and authors. The full terms of this license may be seen at: http://creativecommons.org/licences/by/4.0/legalcode

Vol. 9, No. 8, 2019, Pg. 144 - 151

http://hrmars.com/index.php/pages/detail/IJARBSS

JOURNAL HOMEPAGE

Full Terms \& Conditions of access and use can be found at http://hrmars.com/index.php/pages/detail/publication-ethics 


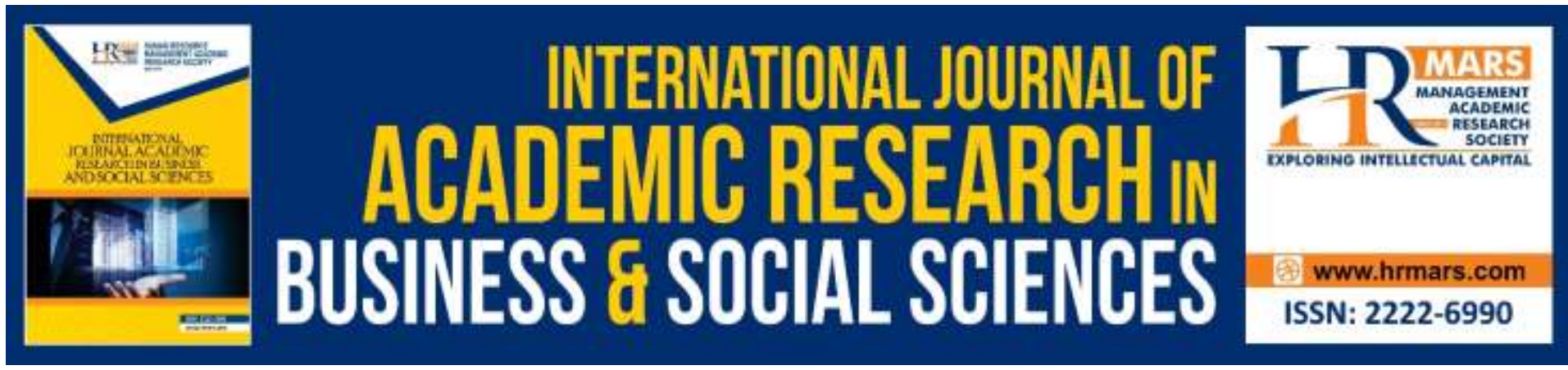

\title{
Airbnb Physical Environment Attributes and Customer Behavioral Intention: A Proposed Study
}

\author{
Normaizana Mat Nawi, Nik Alif Amri Nik Hashim \\ Faculty of Hospitality, Tourism and Wellness, Universiti Malaysia Kelantan, Malaysia \\ Dr. Zurena@Rena Shahril, Dr. Rasidah Hamid \\ Faculty of Hotel and Tourism Management, Universiti Teknologi MARA, Malaysia
}

\begin{abstract}
The development of Airbnb environment in the hospitality and tourism industries has created differentiation for customers to purchase product or service. Throughout years by years, customer behavioural intention has progressed according various side and wish to get more than expected in order to fulfil the needs and wants. Customers usually made accommodation booking through online. The disruptive innovation of Airbnb accommodation is an attractive element that causes customers to beware of Airbnb. In line with this, customers intend to choose accommodation based on the physical environment namely ambience, decoration and layout. However, the poor service of Airbnb such as demand service is not given and Airbnb is still considerably absent in a large number of the field. This paper aimed to examine the literature on the roles of physical environment towards Airbnb behavioural intention. The literature reviews show that there will be a positive relationship between ambience, decoration and layout with behavioural intention among customers. The findings of this study are expected to fill the gap in the literature by extending the knowledge of existing literature on Airbnb behavioural intention.
\end{abstract}

Keywords: Airbnb, Physical Environment, Behavioural Intention

\section{Introduction}

The travel and tourism sector is among the biggest and fastest-growing segments in the global economy. It has grown into a prosperity business accounted for $10.4 \%$ of Gross Domestic Profits (GDP) and 319 million jobs, or 10\% of total employment for the year 2018 (World Travel \& Tourism Council, WTTC2018). The tourism subsector in Malaysia without exception has also earmarked as one of the government's focus areas, and an enabler for the transformation of Malaysia into a high-income nation which had contributed $13.3 \%$ to the national GDP (WTTC2018). 
In reality, tourism and the preference of tourists have evolved over the decades to include a variety of tastes and styles both in terms of more travellers and of a vast choice of products on the market which is highly competitive. These travellers are looking for alternative accommodation from hotels or serviced apartments. Airbnb was created when the two current college graduates changing over their home into an "Air Bed and Breakfast "by offering overnight stay on air mattress amid a San Francisco meeting in 2007 (Guttentag, 2015), Airbnb made a commission-based webstage for room sharers and travellers. Airbnb accommodations basically incorporate a whole home (e.g., loft, condominium, house), or home-sharing (e.g., a private room) in an area where the host is also staying there (Guttentag, \& Smith, Potwarka \& Havitz, 2017). The innovation of Airbnb is an attractive element that has revolutionised the market in accommodation and somehow may strike the hotel industry (Zervas, 2017).

However, customer behavioural intention is affected as according to Phua (2018) said that tourists face trouble of dealing with people that are not professionals who irresponsible behaviour and non-professional hosts created failed on believe and protection of the customer service on behalf of tourists' opinions. Customer purchase conclusion is affected Leland \& Said (2012) depict residents who live close Airbnb housing whining of commotion issues, voicing security concern, and having contrast of conclusion with both Airbnb hosts and visitors. As Airbnb has had a good run, it becomes increasingly important that travel platform blends physical environment attributes and customer behavioural intention to create a more seamless travel journey. What do the future hold for it and the market in which it operates? Therefore to cope with this scenario of being a niche market and relatively new, there are obvious issues between those parameters that need to be discovered. Thus, this study is to enhance the understanding of the physical environment and customer behavioural intention in Malaysia's Airbnb context.

\section{Literature Review \\ Physical Environment}

The physical appearances of the hotels' exterior and open spaces are viewed as two of the most attributes that are identified with having a choice for choosing a hotel to remain (Dube \& Renaghan, 2000). According to Pizam (2005), the physical environment is characterized as the material surroundings of a place. On the other hand, Lee and Jeong (2012) support that the physical environment of the organisation consists of ambience, decoration and layout. The term services cape was used by Bitner, (1992) in describing the manufactured physical environment in which the distribution of product and services takes place. Recently, this phenomenon arises to be a vital part of customer assessment of fulfilment with services (Ruiz, 2012). Previous researches show that sufficient physical environment in this sense results in more promising customer's responses like comfort sensitivity and increase positive verbal trust (Ryu \& Han, 2012).

Furthermore, it is essential to forming an attractive environment as it is a key factor in attracting and satisfying hospitality industry customers, especially among academician and hospitality superiors (Han \& Ryu, 2009). The physical environment is 
one of the crucial elements in distinguishing service organisation and shape the nature of customer experiences (Bitner, 1992). Since physical environment is described as an outward appearance of the service provider, establishing customer expectations can be critical (Simpeh, 2011) through preparing the quality of the intangible service through the tangible indication (Berry \& Parasuraman, 1991). Thus, this study intends to identify the factors of physical environment that influence Airbnb customer's behavioural intention in Malaysia context.

\section{Ambience}

The ambience is another word in the sense of the mood a place or setting has for the atmosphere. An expensive hotel has soft lighting and peaceful music, as well as a pleasant, relaxing ambience. According to Bitner (1992), environmental conditions can be defined as a factor affecting both physical environment perceptions and human responses. In addition, (Berglund, M., \& Halvarsson, Y., 2008) states that the environmental background aspects such as lightning, different kinds of noise, and music and temperature are the ambient conditions. Bitter (2019), has shown that it is very difficult to predict the impact of the ambience on the customer, but all extreme factors can be easily noticed in the approach or avoidance behaviour of the customer, such as loud music, extremely bright light or very low temperatures or vice versa. The ambience is the quality of the surrounding space that customers perceive.

Proposition 1: Ambience is positively related to behavioural intention

\section{Décor}

According to Wakefied \& Blodgett (1994), décor will present to the attractiveness for the surrounding. Décor show a huge role as the marketing strategy by influence customer intention and responses such as satisfaction, behavior, attitude, emotion, price perception and also value perception (Berry \& Wall, 2007; Han and Ryu, 2009; Pullman and Gross, 2004; Pullman and Robson, 2007; Ryu \& Jang, 2007). In line with that, Bitner (1992) décor consider as attention in research on atmospherics which includes exterior and interior design same goes as the ambient condition of service provision. Decoration may be influenced by the colour schemes, wall/ floor covering, furniture, picture/painting, and flower/plant to increase the view quality of area, catch customer emotion and influencing their intention (Ryu \& Han, 2011). In academic research by Ryu \& Jang (2008) typically classified colours, shapes, style, décor, and artwork, usually shortened as "facility aesthetics" and also describe physical environment, including overall layout, decoration, design, and aesthetics (Bogicevic, Bujisic, Cobanoglu \& Feinstein, 2018 ).

Preposition 2: Decor is positively related to behavioural intention

\section{Layout}

The effective spatial layout of the physical environment is very significant because the physical environment in service settings is the purposefully to accomplish and satisfy the specific wants and needs of customers (Bitner, 1992). Based on the needs of the service delivery process from Nguyen \& Leblanc (2002), spatial layout indicates to organizing the object like equipment and furniture. Besides, Bitner (1992), also states 
that accessibility to the layout refers to the organisation of furnishings, equipment, passageways and service areas. Accessibility of the layout should include signage.

Furthermore, Robinson \& Callan (2005), observed in the studies that dimension of accessibility include clear location signage and noticeably signed fire exits and routes. Lee and Kim (2014), indicate that uncomplicated layout is a powerful determinant of perceived quality of services. Moon et al. (2015), agree with the views, point out that layout accessibility and efficiency is important to good physical environments at airports where there are many processes taking place simultaneously like immigration, check-in, security, and service.

Preposition 3: Layout is positively related to behavioural intention

\section{Behavioral Intentions}

Behavioral intention is defined as the degree to which a person has formulated conscious plans to perform or not to perform some specified future behavior (Ajzen \& Fishbein, 1980). The authors emphasize that behavioral intentions are related to actual behaviors of consumers. On the other hand, Quellette, \& Wood (1998) support that behavioral intentions can be a tool to predict future behaviors of consumers. Consumers may generate different behavioral intentions in light of their experiences. For instance, consumers say positive things about the company, recommend the product or service to friends and family, and become loyal by repeating purchase when they have a favorable behavioral intention (Zeithmal et al., 1996). According to the authors, service quality is a determinant in the creation of behavioral intentions of customers, and therefore saying positive things about a product or service, recommending it and being a loyal customer are only possible when perceived quality is high. Similarly, behavioral intentions are considered to include revisit and word-ofmouth intentions (Jani \& Han, 2011).

\section{Proposed Research Framework}

Based on the previous literature, this study proposes a research framework to address the relationship between ambience, décor and layout as the factors that influence customer behavioural intention towards Airbnb physical environment. It is proposed that there is a positive relationship between these variables. 


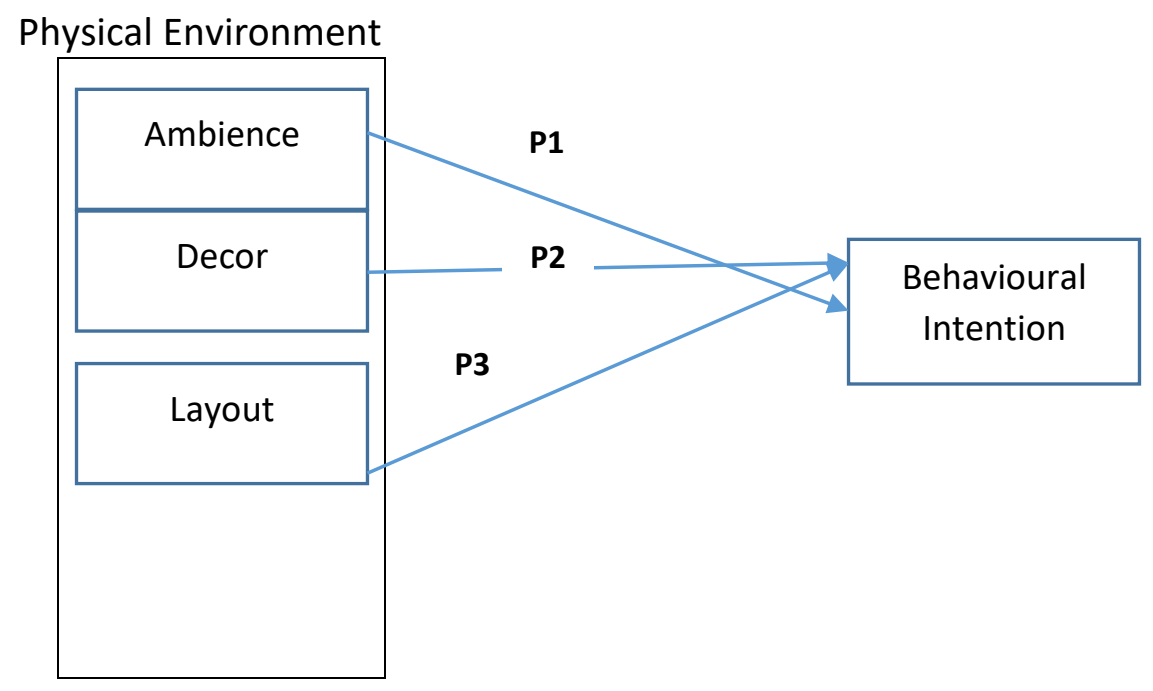

Figure 1: A Proposed conceptual framework

\section{Conclusion}

To date, various dimensions and perspectives of the physical environment have been studied. However, only few studies have touched on the relationship between the physical environment dimensions and customer's actual behavioural intention and none particularly looking at Airbnb accommodation industry. It is hoped that this study will be a recommendation for future customer to choose the best environment that they want and determine the place of physical environment in their choosing with subjects like location, prices or preferences. The most important factor can be determined and contribute to customer knowledge. Airbnb hosts, on the other hand should give importance to ambience, décor and layout of their accommodation in their area. In this way, behavioural intentions of their customers may increase and they may ahead of their competitors. Improving the competitiveness of the accommodation physical environment will attract more customers and will be able to fill the gap in the literature by focusing on the factors that influence physical environment dimension towards customer behavioural intention.

\section{Acknowledgement}

This research did not receive any specific grant from funding agencies in the public, commercial, or not-for-profit sectors.

\section{Corresponding Author}

Nor Maizana Mat Nawi \& Nik Alif Amri Bin Nik Hashim, Faculty of Hospitality, Tourism and Wellness, Universiti Malaysia Kelantan, Malaysia, Email: maizana.mn@umk.edu.my \& nikalifamri@gmail.com 


\section{References}

Razli, W. I., A Jamal, S., \& Mohd Zahari, M. S. (2017). Perceived value in peer-to-peer (P2P) accommodation: A case of Airbnb. Perceived value in peer-to-peer (P2P) accommodation: A case of Airbnb, Journal of Tourism, Hospitality \& Culinary Arts, 9 (2), 213-224.

Berglund, M., \& Halvarsson, Y. (2008). Managing The Physical Environment In Services Organizations: A Case Study Of The Servicescape's Affect On Relationships Between Customers And Employees (Bachelor Thesis, Lulea University of Technology

Parasuraman, A., Berry, L. L., \& Zeithaml, V. A. (1991). Refinement and reassessment of the SERVQUAL scale. Journal of Retailing, 67(4), 420.

Bitner, M. J. (1992). Servicescapes: The Impact of Physical Surroundings on Customers and Employees. Journal of Marketing, 56(2), 57-71.

Bogicevic, V., Bujisic, M., Cobanoglu, C., \& Feinstein, A. H. (2018). Gender And Age Preferences of Hotel Room Design. International Journal of Contemporary Hospitality Management, 30(2), 874-899.

Dubé, L., \& Renaghan, L. M. (2000). Creating Visible Customer Value: How Customers View Best-Practice Champions. Cornell Hotel And Restaurant Administration Quarterly, 41(1), 62-72.

Fishbein, M., Jaccard, J., Davidson, A. R., Ajzen, I., \& Loken, B. (1980). Predicting and understanding family planning behaviors. In Understanding attitudes and predicting social behavior. Englewood Cliffs:Prentice Hall.

Forgacs, G., \& Dimanche, F. (2016). Revenue Challenges For Hotels In The Sharing Economy: Facing The Airbnb Menace. Journal of Revenue and Pricing Management, 15(6), 509-515.

Guttentag, D. (2015). Airbnb: disruptive innovation and the rise of an informal tourism accommodation sector. Current issues in Tourism, 18(12), 1192-1217.

Jani, D., \& Han, H. (2011). Investigating The Key Factors Affecting Behavioral Intentions:Evidence From A Full-Service Restaurant Setting. International Journal of Contemporary Hospitality Management, 23(7), 1000-1018.

Lee, S. M., Kim, Y. S., \& Tak-Ki, Y. U. (2014). U.S. Patent No. 8,660,568. Washington, DC: U.S. Patent and Trademark Office.

Lee, S., \& Jeong, M. (2012). Effects of E-Servicescape on Consumers' Flow Experiences. Journal of Hospitality and Tourism Technology, 3(1), 47-59.

Moon, H., Sharma, R., \& Jung, N. (2011). U.S. Patent No. 7,912,246. Washington, DC: U.S. Patent and Trademark Office.

Ouellette, J. A., \& Wood, W. (1998). Habit And Intention In Everyday Life: The Multiple Processes By Which Past Behavior Predicts Future Behavior. Psychological bulletin, 124(1), 54.

Robinson, L. S., \& Callan, R. J. (2005). UK Conference Delegates' Cognizance of The Importance of Venue Selection Attributes. International Journal of Convention \& Event Tourism, 7, (1), 77-95.

Ryu, K., Lee, H. R., \& Kim, G. W. (2012). The Influence of The Quality of The Physical Environment, Food, And Service on Restaurant Image, Customer Perceived Value, Customer Satisfaction, and Behavioral Intentions. International Journal of Contemporary Hospitality Management, 24(2), 200-223. 
Simpeh, K. N., Simpeh, M., Nasiru, I., \& Tawiah, K. (2011). Servicescape and customer patronage of three star hotels in Ghana's metropolitan city of Accra. European Journal of Business and Management, 3(4), 119-131.

Wakefield, K. L., \& Blodgett, J. G. (1994). The Importance Of Servicescapes In Leisure Service Settings. Journal of services marketing, 8(3), 66-76.

Yang, Y., Tan, K. P. S., \& Li, X. R. (2019). Antecedents and Consequences of HomeSharing Stays: Evidence From A Nationwide Household Tourism Survey. Tourism Management, 70, 15-28.

Yekanialibeiglou, S. (2015). The Influence of DINESCAPE on emotions and behavioral intentions of customers (Doctoral dissertation, Bilkent University).

Zeithaml, V. A., Berry, L. L., \& Parasuraman, A. (1996). The Behavioral Consequences of Service Quality. Journal of Marketing, 60(2), 31-46.

Zervas, G., Proserpio, D., \& Byers, J. W. (2017). The Rise of The Sharing Economy: Estimating The Impact Of Airbnb On The Hotel Industry. Journal of Marketing Research, 54(5), 687-705. 